\title{
An Empirical Study of Climate Change on Carbon Dioxide Emission in ASEAN 4: Vector Autoregression Exogenous (VARX) Approach
}

\author{
By: \\ Panji Tirta Nirwana Putra ${ }^{1^{*}}$, Lilis Yuliati $^{1}$, Endah Kurnia Lestari ${ }^{11}$ \\ ${ }^{1)}$ Faculty of Economics and Business, University of Jember \\ ${ }^{*}$ Corresponding Author: panjitirta63@gmail.com
}

Submission: 26 June 2019, Accepted: 23 August 2019

\begin{abstract}
Climate change is a phenomenon of environmental damage due to the increased intensity of carbon dioxide emissions in the atmosphere, which causes the surface temperature of the earth. The carbon dioxide emission is a form of environmental degradation caused by economic activities. This study analyzed the relationship of macroeconomic variables and the carbon dioxide emission in each of the four ASEAN countries (Indonesia, Malaysia, the Philippines, and Thailand). The used of macroeconomic variables (GDP, trade openness, energy consumption, and the exchange rate) is shown to explain the dynamics of carbon dioxide emission. In this study, Vector Auto regression Exogenous (VARX) method is used to analyze the impact of economic activities on the movement of carbon dioxide emissions. The data used time series with a vulnerable time of the year 1981-2013. The estimation results from these studies show that the GDP variable has the greatest contribution to the dynamics of carbon dioxide emissions in each ASEAN 4 countries. This empirical finding suggests that economic activity has an influence on the growth of carbon dioxide emissions.
\end{abstract}

Keywords: Macroeconomics Variables, Carbon dioxide Emission, VARX, ASEAN 4.

\begin{abstract}
ABSTRAK
Perubahan iklim adalah fenomena kerusakan lingkungan akibat meningkatnya intensitas emisi karbon dioksida di atmosfer dan menyebabkan suhu permukaan bumi. Emisi karbon dioksida adalah bentuk degradasi lingkungan yang disebabkan oleh kegiatan ekonomi. Studi ini menganalisis hubungan indikator ekonomi makro dengan emisi karbon dioksida di masing-masing dari empat negara ASEAN (Indonesia, Malaysia, Filipina, dan Thailand). Penggunaan variabel makroekonomi (PDB, keterbukaan perdagangan, konsumsi energi, dan nilai tukar) ditunjukkan untuk menjelaskan dinamika emisi karbon dioksida. Dalam penelitian ini metode analisis VARX digunakan untuk menganalisis dampak kegiatan ekonomi terhadap pergerakan emisi karbon dioksida. Data yang digunakan adalah data time series dengan waktu rentan tahun 1981-2013. Hasil estimasi dari studi ini menunjukkan bahwa variabel PDB memiliki kontribusi terbesar terhadap dinamika emisi karbon dioksida di setiap negara ASEAN 4. Temuan empiris ini menunjukkan bahwa kegiatan ekonomi memiliki pengaruh terhadap pertumbuhan emisi karbon dioksida.
\end{abstract}

Kata Kunci: Variabel Makroekonomi, Emisi Karbondioksida, VARX, ASEAN 4 


\section{INTRODUCTION}

Global warming is one of environmental damage phenomena in the globalization era. It is closely related to energy consumption and production which affect the quality of air that can cause pollution (Gowdy, 2008; Daniels, 2010; Halkos and Tsilika, 2017). In fact global warming arises from changes in the average temperature of the earth's surface and then will have an impact on climate change (Zhu et al. 2016; Goodman 2016). Climate change is caused by human activity in the use of excessive fossil fuel and it is a real issue that threatens the natural systems, including extinctions and loss of biodiversity (Brown, Henze and Milford, 2017; Chalise et al., 2017; Abrahamson 2015; Anderson \& Gonigle 2012). This condition signaled that an increase in the average temperature of the earth's surface could provide a threat to climate change on earth.

Report of the National Aeronautics and Space Administration (NASA, 2017) suggests that the increase in the average temperature of the earth's surface is at a dangerous level. In recent decades the increase in the earth's surface temperature has been recorded at $20 \mathrm{C}$, where the increase in the average temperature of the earth's surface is equal to 0,80 $\mathrm{C}$ prior to industrialization (Abrahamson, 2015; Chen, Chen and Xu, 2016; Ding et al. , 2016). Increase in the average temperature of the earth's surface is also followed by the increase of carbon dioxide emissions in the world (Rosen and Guenther, 2016; Spalding-fecher, Joyce and Winkler, 2017). These conditions further confirm that climate change is based on the earth's surface temperature rose which is caused by the increasing of carbon dioxide emissions (Vale, 2016; Yu et al., 2016; Zhang and Chen, 2017).

Empirical finding on the risk of global warming from economic standpoint has been done in various countries. Apergis (2015) showed that there is a nonlinear relationship between emissions per capita and personal income per capita in various countries. Later, Omri et al. (2014) investigated the determination of carbon dioxide emissions in Europe and central Asia, Latin America and the Caribbean, and the Middle East, northern Africa, and sub-Saharan Africa. The results show that there is causal relationship at all sub-panels, which is two-way causality between economic growth and FDI inflows for all four panels. these results indicate that there is a relationship between macroeconomic indicators and carbon dioxide emissions in Europe and central Asia, Latin America and the Caribbean, and the Middle East, northern Africa, and sub-Saharan Africa. Halicioglu (2009) in Turkey, shows that there is a long-term relationship between the carbon dioxide that is affected by energy consumption, income, and foreign trade.

Economic growth is an object a country wants to achieve through several economic sectors (Ng'ang'a et al., 2016; Halkos and Tsilika, 2017). Industrial and commercial sector contributed greatly to the economic growth. In addition, industrial and commercial sector contribute most to global warming (Rosen and Guenther, 2016; Tsigaris and Wood, 2016; Spalding-fecher, Joyce and Winkler, 2017). The importance of appropriate strategies and policies in reducing the impact of global warming through carbon dioxide emissions reduction policy is expected to reduce the risk of climate change. this study focus to analyze the dynamics of global warming represented as carbon dioxide emissions in ASEAN 4 (Indonesia, Malaysia, the Philippines and Thailand) as a result of economic activities. The selection of macroeconomic variables is expected to be able to describe the dynamics of carbon dioxide emissions in ASEAN 4.

\section{METHOD}

The data used in this study were the macroeconomic variables GDP (US \$), trade (\% of GDP), energy consumption ( $\mathrm{kg}$ oil / capita), and the exchange rate (US \$) on carbon dioxide emissions in ASEAN 4 during 1975 -2013. The method used is Vector Auto Regression (VARX), where the addition of exogenous variables becomes dissociation with the standard VAR model. Exogenous variables that are intended are variables outside the standart VAR model. This research model specification is adapted from the research by Kasman and Duman (2014), namely:

$$
C \mathrm{O}_{2}=f(L G D P, T, E N, E X C)
$$


Where $\mathrm{CO} 2$ is carbondioxide emission, GDP is GDP, T is trade, EN is energy consumption and EXC is exchange rate in ASEAN 4.

The model generate to econometric model is as follow:

$$
C O 2_{t}=\alpha_{0}+\beta_{1} L G D P_{t}+\beta_{1} T_{t}+\beta_{1} E N_{t}+\beta_{1} E X C_{t}+\varepsilon_{t}
$$

And generate to VARX model is as follow:

$$
\begin{aligned}
& C O 2_{t}=\alpha_{10}+\beta_{11} L G D P_{t-1}+\beta_{12} T_{t-1}+\beta_{3} E N_{t} * E X C_{t-1}+\varepsilon_{t} \\
& L G D P_{t}=\alpha_{20}+\beta_{21} C O 2_{t-1}+\beta_{22} T_{t-1}+\beta_{23} E N_{t} * E X C_{t-1}+\varepsilon_{t} \\
& T_{t}=\alpha_{30}+\beta_{31} C O 2_{t-1}+\beta_{32} L G D P_{t-1}+\beta_{33} E N_{t} * E X C_{t-1}+\varepsilon_{t} \\
& E N_{t}=\alpha_{40}+\beta_{41} L G D P_{t-1}+\beta_{42} T_{t-1}+\beta_{44} E N_{t} * E X C_{t-1}+\varepsilon_{t}
\end{aligned}
$$

\section{RESULTS AND DISCUSSION}

Estimation test of cumulative sum (CUSUM) and cumulative sum of square (CUSUMQ) model stability is used to test the stability of the model this study. Model stability test is important to test the model used as a basis for forecasting and stimulus of a policy (Hanif, 2011; Ariwa et al., 2017). CUSUM and CUSUMQ test results are illustrated in Figure 1 which shows that the model parameters and residual variance are stable.
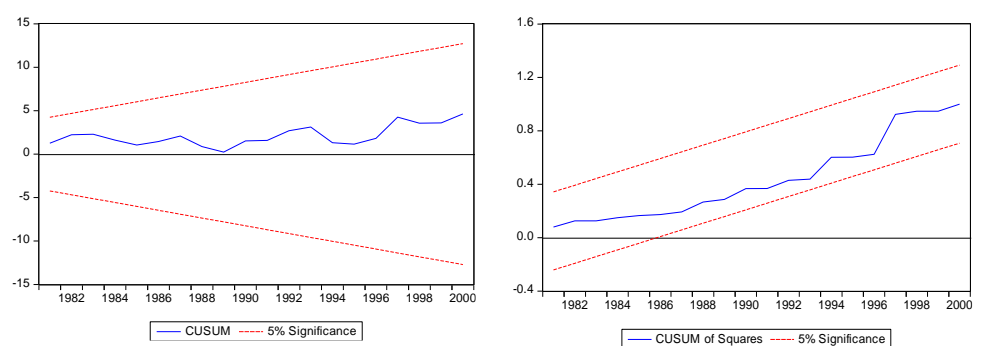

Figure 1. Results of CUSUM and CUSUMQ test

Granger causality test applied in this study is to explain the causal relationship among the variables (Yu et al., 2015; Yao, Lin and Lin, 2016). The relation needed is to look at the reciprocal relationships among the variables observed. Table 1 is the results of Granger Causality analysis in ASEAN 4.

Table 1. Results of Granger Causality test in ASEAN 4

\begin{tabular}{lcccc}
\hline \multirow{2}{*}{ Causality } & Indonesia & Malaysia & The Philippines & Thailand \\
\cline { 2 - 5 } & Lag 1 & Lag 1 & Lag 1 & Lag 3 \\
\hline GDP does not Granger Cause CO2 & - & - & - & - \\
T does not Granger Cause CO2 & - & - & - & - \\
DENRG does not Granger Cause CO2 & $V$ & - & - & - \\
EXC does not Granger Cause CO2 & - & $V$ & $V$ & - \\
T does not Granger Cause GDP & $V$ & - & - & - \\
EN does not Granger Cause GDP & - & - & - & - \\
EXC does not Granger Cause GDP & - & - & - & - \\
EN does not Granger Cause T & - & - & - & $V$ \\
EXC does not Granger Cause T & $V$ & - & $V$ & - \\
EXC does not Granger Cause EN & - & $V$ & $V$ & - \\
\hline VI)
\end{tabular}

$(v)=$ Have Relationship

$(-)=$ Not Have Relationship

Table 1 shows the results of Granger Causality test that if the probability value is $<5 \%$, then the variables observed show mutual influential relationship. Variable Indonesia has a unidirectional relationship indicated by a $\mathrm{CO} 2$ affects energy, trades affect the GDP, and exchange rate affects trades. 
Result of Granger Causality in Malaysia show that only exchange rates affect $\mathrm{CO} 2$ and trades. Exchange rates value of Philippines has a unidirectional relationship which is influenced by $\mathrm{CO} 2$, trades, and energy. Results of Granger Causality in Thailand show that only energy affects trades.

The empirical analysis results of VARX show different behavior among macroeconomic variables in influencing carbon dioxide emissions as a proxy of global warming form in ASEAN 4 both short and long terms. VARX has some important tests including Stationarity data test, cointegration test, optimum lag selection, Impulse Response Function (IRF), and variance decomposition (VD).

Table 2. Stationery Test Data

\begin{tabular}{rrrrr}
\hline Indonesia & Prob. $\mathrm{CO}_{2}$ & Prob. Log GDP & Prob. Trade & Prob. Energy Consumption \\
\hline Level & 0.9953 & 0.9389 & 0.0521 & 0.9627 \\
$1^{\text {st }}$ Difference & $0.0000^{*}$ & $0.0000^{*}$ & $0.0000^{*}$ & $0.0000^{*}$ \\
\hline Malaysia & Prob. CO & Prob. Log GDP & Prob. Trade & Prob. Energy Consumption \\
\hline Level & 0.9493 & 0.7476 & 0.5625 & 0.9184 \\
$1^{\text {st }}$ Difference & $0.0000^{*}$ & $0.0003^{*}$ & $0.0009^{*}$ & $0.0000^{*}$ \\
\hline The Philippines & Prob. CO & Prob. Log GDP & Prob. Trade & Prob. Energy Consumption \\
\hline Level & 0.7153 & 0.9322 & 0.3759 & 0.3153 \\
$1^{\text {st }}$ Difference & $0.0004^{*}$ & $0.0028^{*}$ & 0.2289 & $0.0040^{*}$ \\
\hline Thailand & Prob. CO & Prob. Log GDP & Prob. Trade & Prob. Energy Consumption \\
\hline Level & 0.9919 & 0.7096 & 0.9144 & 0.9984 \\
$1^{\text {st }}$ Difference & $0.0031^{*}$ & $0.0042^{*}$ & $0.0000^{*}$ & $0.0004^{*}$ \\
\hline
\end{tabular}

*Stationary at $\alpha=5 \%$

Augmented Dicky-Fuller (ADF) stationarity test is applied to test the unit root test from the data used in this study, if the value of the probability is $A D F<\alpha$ then the data considered to be stationer. Estimation results show all variables in ASEAN 4 are at the first difference level of stationarity which is indicated by the value of probability $A D F<\alpha$.

Table 3. Cointegration Test

\begin{tabular}{ccrrr}
\hline Country & A & Critical Value & Trace Statistic & Cointegration \\
\hline \multirow{3}{*}{ Indonesia } & $1 \%$ & 72.2356 & 54.6815 & Not Cointegrated \\
& $5 \%$ & 72.2356 & 47.85613 & Not Cointegrated \\
& $10 \%$ & 88.03182 & 65.8197 & Not Cointegrated \\
\cline { 2 - 5 } Malaysia & $1 \%$ & 84.49708 & 54.6815 & Not Cointegrated \\
& $5 \%$ & 84.49708 & 47.85613 & Not Cointegrated \\
The & $10 \%$ & 87.16629 & 65.8197 & Not Cointegrated \\
\cline { 2 - 5 } Philippines & $1 \%$ & 87.30363 & 54.6815 & Not Cointegrated \\
& $10 \%$ & 87.30363 & 47.85613 & Not Cointegrated \\
Thailand & $1 \%$ & 108.30363 & 44.49359 & Not Cointegrated \\
& $5 \%$ & 108.6555 & 54.6815 & Not Cointegrated \\
& $10 \%$ & 108.6555 & 47.85613 & Not Cointegrated \\
\hline
\end{tabular}

Cointegration test results shown in Table 3 shows that, the all variables used are not cointegrated so that the model used in VARX is a short-term model. These results were obtained from the trace statistic value that is smaller than the critical value in each of the ASEAN countries 4. 
Table 4. Optimum Lag Test

\begin{tabular}{ccccc}
\hline Lag & AIC (Indonesia) & AIC (Malaysia) & AIC (The Philippines) & AIC (Thailand) \\
\hline 0 & 11.20205 & 16.39117 & 7.23363 & 11.6958 \\
1 & $10.70012^{*}$ & $16.26224^{*}$ & $6.921352^{*}$ & 10.9104 \\
2 & 0 & 16.77072 & 6.924491 & 10.90673 \\
3 & 0 & 16.73795 & 7.148003 & $10.85426^{*}$ \\
\hline
\end{tabular}

*The lowest AIC value

In this study, the optimum lag test is presented in Table 4. Determination of the proper lag aims to liberate the model of autocorrelation problem and to determine vulnerable time period of variables' mutual influential relationship to the other endogenous variables. Determination of the lag used in this study is the Akaike Information Criteria (AIC). The estimation results of optimum lag with AIC (Akaike Information Criterion) method show that Indonesia, Malaysia, and the Philippines have lag optimum value in the third lag. optimum value equation VAR at the first lag, then to Thailand have the optimum lag at the third lag.

The next important test used in VARX analysis is Impulse Response Function (IRF) and variance development (VD). IRF is aimed to know the response of one of the variables due to internal shocks on the other variables. Meanwhile, VD analysis is used to see the contribution due to shocks on variables.

The result of Impulse Response function is illustrated in Figure 2. $\mathrm{CO}_{2}$ variable have different responses in responding to changes in macroeconomic variable. When GDP variable is in the $2^{\text {nd }}$ period, it is responded by $\mathrm{CO}_{2}$ variable until the $10^{\text {th }}$ period. If shock is at trade variable in the $2^{\text {nd }}$ period, it is responded by $\mathrm{CO}_{2}$ variable until the $6^{\text {th }}$ period. Then when shock is at the consumption energy variable is responded by $\mathrm{CO}_{2}$ in the $1^{\text {st }}$ period until the $5^{\text {th }}$ period.
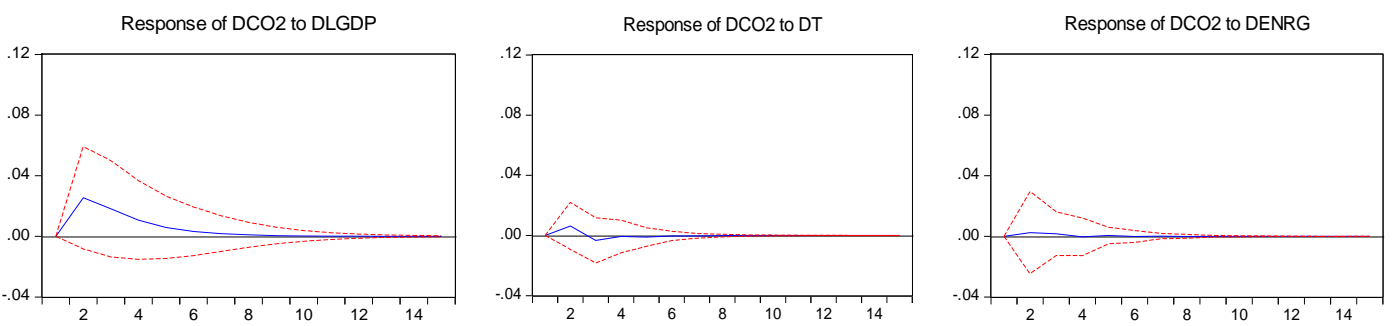

Figure 2. Impulse Response Function in Indonesia

Results of Impulse Response in Indonesia illustrates that shock on the macroeconomic variables will be responded to by $\mathrm{CO}_{2}$ variable in a short time span. Response of $\mathrm{CO}_{2}$ variable to the turmoil in macroeconomic variables has different movements. $\mathrm{CO}_{2}$ responded GDP until the 10th period, and then the trade variable is up to the $7^{\text {th }}$ period, and energy consumption variable up to the $7^{\text {th }}$ period.

Table 5. Variance Decomposition in Indonesia

\begin{tabular}{rrrrrr}
\hline Period & S.E. & CO2 & GDP & T & EN \\
\hline 1 & 0.064331 & 100 & 0 & 0 & 0 \\
2 & 0.084935 & 90.42238 & 8.950604 & 0.543662 & 0.083353 \\
3 & 0.093342 & 88.12207 & 11.19947 & 0.574958 & 0.103501 \\
4 & 0.095898 & 87.48444 & 11.86659 & 0.549825 & 0.099148 \\
11 & 0.096983 & 87.21383 & 12.13393 & 0.551838 & 0.100398 \\
12 & 0.096983 & 87.2138 & 12.13397 & 0.551837 & 0.100398 \\
13 & 0.096983 & 87.21379 & 12.13398 & 0.551837 & 0.100398 \\
14 & 0.096983 & 87.21378 & 12.13398 & 0.551837 & 0.100398 \\
15 & 0.096983 & 87.21378 & 12.13398 & 0.551837 & 0.100398 \\
\hline
\end{tabular}


Table 5 is the result of analysis of variance decomposition in Indonesia in explaining the contribution of macroeconomic variables on the movement of $\mathrm{CO}_{2}$. Overall LGDP variables contributed most to $\mathrm{CO}_{2}$ in Indonesia. LGDP contribution to $\mathrm{CO}_{2}$ is equal to $12.13 \%$.

The Results of impulse Response function in Malaysia are depicted in Figure 3. The results impulse Response function in Malaysia illustrate that during a shock in GDP in the second period, $\mathrm{CO}_{2}$ variable responds to the equilibrium point in the 6 th period. Furthermore, during shock on the trade variable, it is responded by $\mathrm{CO}_{2}$ variable to the equilibrium point in the 5 th period. Then, during shock on energy consumption variable in the second period, $\mathrm{CO}_{2}$ variable responds until the 5 th period. In general, this condition illustrates that $\mathrm{CO}_{2}$ variable in Malaysia responds the turmoil on the macroeconomic variables in the short term.
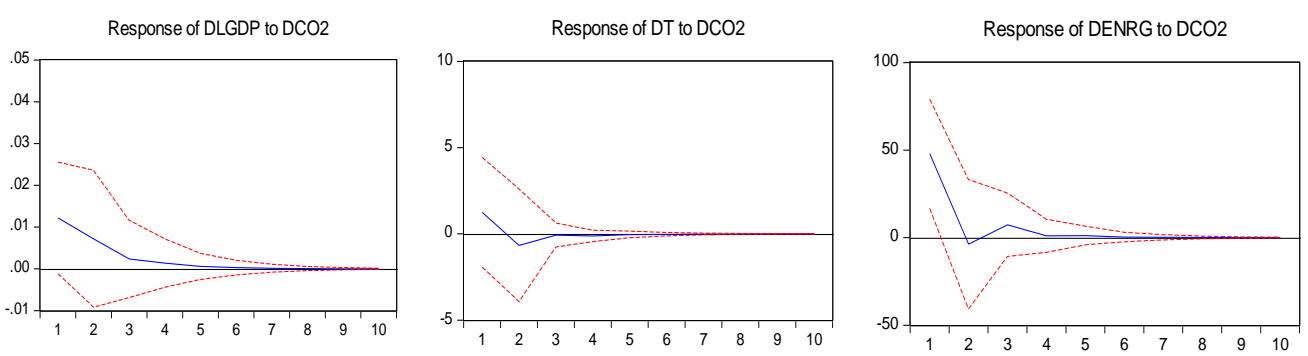

Figure 3: Impulse Response Function in Malaysia

Table 6 is the result of the analysis of Variance Decomposition (VD) in explaining the contribution of macroeconomic variables on the movement of $\mathrm{CO} 2$ in Malaysia. The results of VD analysis can be concluded that LGDP variable had the largest contribution to $\mathrm{CO} 2$ in Malaysia which amounted to $14.77 \%$ at the beginning of the period and continued to increase to $16.38 \%$ at the end of the period.

Table. 6 Variance Decomposition in Malaysia

\begin{tabular}{crrrrr}
\hline Period & S.E. & \multicolumn{1}{l}{ CO2 } & \multicolumn{1}{l}{ GDP } & \multicolumn{1}{c}{ T } & \multicolumn{1}{c}{ EN } \\
\hline 1 & 0.375926 & 100 & 0 & 0 & 0 \\
2 & 0.414331 & 83.66739 & 14.77305 & 1.534072 & 0.025487 \\
3 & 0.419973 & 82.0352 & 15.68186 & 1.677358 & 0.60558 \\
4 & 0.421823 & 81.3181 & 16.25867 & 1.784495 & 0.63874 \\
5 & 0.422195 & 81.18459 & 16.34912 & 1.806456 & 0.659825 \\
6 & 0.422292 & 81.14751 & 16.37658 & 1.813299 & 0.662608 \\
7 & 0.422312 & 81.13987 & 16.38187 & 1.814785 & 0.663468 \\
8 & 0.422317 & 81.13808 & 16.38315 & 1.81515 & 0.663619 \\
9 & 0.422318 & 81.1377 & 16.38341 & 1.815228 & 0.663656 \\
10 & 0.422318 & 81.13762 & 16.38347 & 1.815246 & 0.663663 \\
\hline
\end{tabular}

Results of Impulse Response function of Philippines are depicted in Figure 4. Carbon dioxide emissions variable have a different response in reacting to changes in macroeconomic variables. When there found a shock on GDP variable in the $2^{\text {nd }}$ period, it is responded by $\mathrm{CO}_{2}$ variable to the $8^{\text {th }}$ period. During the shock on the trade variables in period $2, \mathrm{CO}_{2}$ variable responds until the $4^{\text {th }}$ period. Then during the shock of energy consumption variable, $\mathrm{CO}_{2}$ variable responds in the $2^{\text {nd }}$ period up to the $5^{\text {th }}$ periods. 

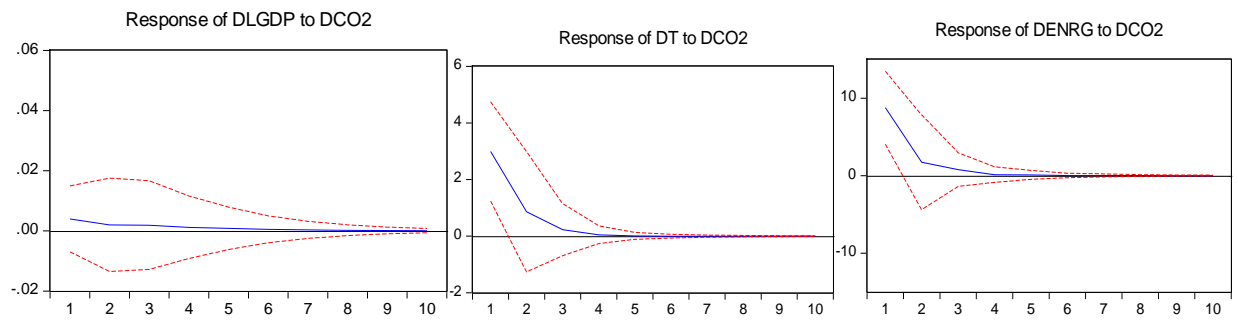

Figure 4: Impulse Response Function in the Philippines

Results of Impulse Response in Philippines illustrate that in responding to the turmoil on the macroeconomic variables, it will be responded by $\mathrm{CO}_{2}$ variable in a short time span. $\mathrm{CO}_{2}$ variable response to the turmoil in macroeconomic variables has different movements. This condition suggests that when there is a shock on GDP variable, it takes 6 periods for $\mathrm{CO}_{2}$ variable to achieve equilibrium point, then trade variable takes three periods, and energy consumption variable takes 4 period.

Table 7. Variance Decomposition in the Philippines

\begin{tabular}{clllll}
\hline Period & S.E. & \multicolumn{1}{c}{ CO2 } & \multicolumn{1}{c}{ GDP } & \multicolumn{1}{c}{ T } & \multicolumn{1}{c}{ EN } \\
\hline 1 & 0.046177 & 100 & 0 & 0 & 0 \\
5 & 0.04849 & 96.8364 & 1.22809 & 0.890169 & 1.045338 \\
6 & 0.048503 & 96.78841 & 1.268116 & 0.894865 & 1.048613 \\
7 & 0.048507 & 96.77091 & 1.282588 & 0.897509 & 1.048995 \\
8 & 0.048509 & 96.76367 & 1.288466 & 0.89853 & 1.049333 \\
9 & 0.04851 & 96.761 & 1.290632 & 0.898955 & 1.04941 \\
10 & 0.04851 & 96.75996 & 1.291476 & 0.899113 & 1.049451 \\
\hline
\end{tabular}

Table 7 is the result of the analysis of Variance Decomposition (VD) in explaining the contribution of macroeconomic variables on the movement of $\mathrm{CO}_{2}$ in Philippines. The results of VD analysis can be concluded that LGDP variable has contributed to $\mathrm{CO}_{2}$ about $1.29 \%$ in $9^{\text {th }}$ period, the trade variable contribute to $\mathrm{CO}_{2}$ about $1.89 \%$ in all period, and energy consumption $1.04 \%$ in $10^{\text {th }}$ period.

The Results of Impulse Response function of Thailand are depicted in Figure 5. Carbon dioxide emissions have different response in reacting to changes in macroeconomic variables. When there is a shock in the LGDP variable in the 2 nd period, it is responded by $\mathrm{CO} 2$ variable until the end of the period. During the shock in trade variables in the $2^{\text {nd }}$ period, it is also responded by $\mathrm{CO} 2$ variable until the end of the period. Then the shock of energy consumption variable is responded by $\mathrm{CO} 2$ variable until the end of the period. This condition suggests that it took a relatively long time to reach the point of equilibrium for $\mathrm{CO} 2$ variable during turmoil on macroeconomic variables.
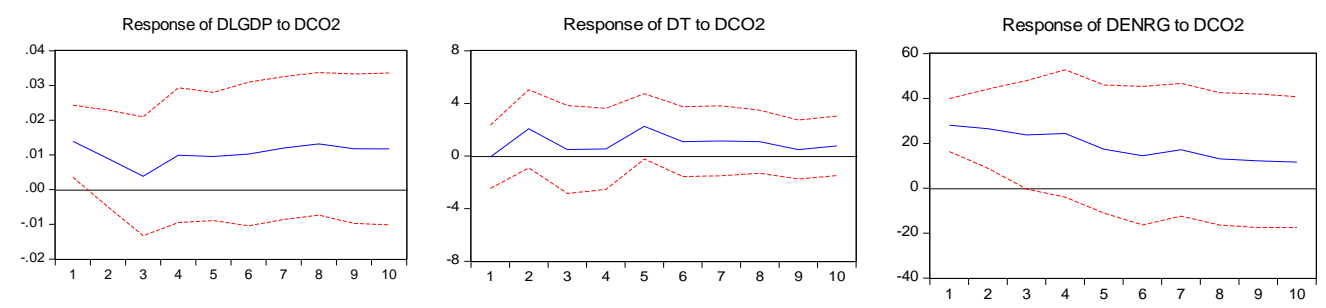

Figure 5 Impulse Response function in Thailand

Table 8 is the result of the analysis of Variance Decomposition (VD) in explaining the contribution of macroeconomic variables on the movement of $\mathrm{CO}_{2}$ in Thailand. The results of the analysis of VD can be concluded that each of the macroeconomic variables have contributed to $\mathrm{CO}_{2}$ in Thailand. GDP 
variable has the largest contribution to the $\mathrm{CO}_{2}$ in Thailand with a contribution of $10,96 \%$ in $5^{\text {th }}$ period. Furthermore, the trade variable has a contribution of $3,63 \%$ in $8^{\text {th }}$ period toward $\mathrm{CO}_{2}$, and then to the energy consumption contributed $5,02 \%$ in $9^{\text {th }}$ period.

Table 8. Variance Decomposition in Thailand

\begin{tabular}{cccccc}
\hline Period & S.E. & CO2 & GDP & T & EN \\
\hline 1 & 0.137008 & 100 & 0 & 0 & 0 \\
2 & 0.156798 & 93.82934 & 4.07975 & 0.451535 & 1.639377 \\
3 & 0.18292 & 84.17981 & 10.54671 & 3.020279 & 2.253204 \\
4 & 0.191427 & 85.21003 & 9.82744 & 2.815634 & 2.146893 \\
5 & 0.198961 & 82.78859 & 10.96033 & 3.642677 & 2.608409 \\
6 & 0.205305 & 81.54881 & 10.64884 & 3.510783 & 4.291568 \\
7 & 0.209618 & 82.23178 & 10.25385 & 3.388098 & 4.126268 \\
8 & 0.214187 & 81.11213 & 10.37121 & 3.636069 & 4.880592 \\
9 & 0.217402 & 81.36569 & 10.07975 & 3.530972 & 5.023583 \\
10 & 0.219422 & 81.57846 & 9.950131 & 3.518573 & 4.952832 \\
\hline
\end{tabular}

The results of VARX test for Indonesia show that all the macroeconomic variables contribute to the increasing of carbon dioxide emissions. This condition is further confirmed that the increase in economic activity in Indonesia contributes to climate change (Arvin, Pradhan and Norman, 2015; Ang and Goh, 2016; Apergis, 2016; Wardhono et al., 2016). The proportion of determination of carbon dioxide emissions in Indonesia comes from the energy consumption of government, private sector, industry, and transportation (Colenbrander et al., 2015; Jaung et al., 2016). The situation is also supported by the use of environmentally friendly energy that is not used in economic activities. In addition, the frequent occurrence of fires in the forest from land clearing in Indonesia that occur almost every year also support the increasing of carbon dioxide and the risk of global warming (Medrilzam et al., 2017). Increase in the technological changes which is more efficient affect on the efficiency and effectiveness on energy use (Othman et al., 2009; Mujiyanto and Tiess, 2013; Skidmore, Santos and Leimona, 2014). In addition, the area of tropical rain forest that is widely spread in Indonesia is also responsible for keeping the cycle of carbon dioxide emissions in Indonesia and in the world so that the risk of increase in carbon dioxide emissions will able to be reduced by the availability of green land (Mujiyanto and Tiess, 2013; Colenbrander et al., 2015 ).

Malaysia showed that GDP variable has a major contribution to the dynamics of carbon dioxide emissions. This situation illustrates that the increase in economic activity in Malaysia is followed by an increase in the level of carbon dioxide emissions in Malaysia (Othman et al., 2009; Mugableh, 2013). It is also confirmed that the risk of the increase in climate change in Malaysia is contributed by sectors of the economy. Economic sector in Malaysia is supported by an increase in industrial and commercial sector (Chandran and Tang, 2013). These results are consistent with empirical findings and rejected the findings of empirical research (Saboori and Mohd, 2012; Mugableh, 2013).

Empirical findings in Philippines showed that the GDP variable contributes greatly to the carbon dioxide emissions in Philippines. This is supported by the Philippine trade levels which is growing and increasing trading volume (Wu et al., 2014; Thompson et al. 2014; Cabalu et al. 2015). This condition illustrates that the increased risk of global warming in Philippines contributed by sectors of the economy. The empirical findings of this study support from Ang \& Goh 2016; Zakarya et al. For 2015 and concluded that there is a relationship between macroeconomic variables on carbon dioxide emissions in the Philippines

Testing Results VARX in Thailand showed that the trade and exchange rate variables greatly affect the determination of carbon dioxide emissions. However, the contribution given by macroeconomic variables have not been as contributed by the macroeconomic variables in that other State. This finding 
suggests that the determination of carbon dioxide in Thailand is affected by macroeconomic variables, with small contribution. Determination of carbon dioxide emissions in Thailand is contributed by the agricultural and industrial sectors.

Biofuel policy is issued by the government to tackle the phenomenon of climate change caused by an increase in carbon dioxide emissions. Each of the four ASEAN countries has strategies and policies which are applied, this condition is related to the state of the economy in each of the ASEAN 4 countries. The use of fossil fuels that are not environmentally friendly in economic activity adds to the risk of changing seasons. This is caused by the use of fossil fuels which increased the emissions of carbon dioxide in each of the ASEAN 4 countries. Policies in the use of fossil fuels have been conducted in each of the ASEAN 4 countries.

Biofuel policies in Indonesia aim to develop and maximize the potential of alternative fuels that can be renewed. Potential biofuel alternative energy sources in Indonesia is Jarak plants and palm oil . Biofuel policies in Indonesia for the first time is the Presidential Instruction No. 1 of 2006, which contains about maximizing the potential of renewable resources by facilitating alternative, research, supply, integration of biofuels. Then the next policy is a policy-setting blending of biofuels as an alternative energy source to improve fuel efficiency and maximize economic development from central to local (National Energy Policy (Presidential Decree No. 5 of 2006), the Energy Act No. 30 of 2007).

Malaysian Biofuel policy is implemented to reduce the impact of carbon dioxide emissions as well as through several policies towards renewable biofuels alternative energy sources (Lopez and Laan, 2008; Chin, 2011; Wahab, 2013). It is closely linked with the efforts to reduce dependence on fossil fuel energy sources which is not renewable and can cause carbon dioxide emissions. The biofuel policy in Malaysia is started with the National Biofuel Policy which was inaugurated on March 21, 2006 (Wahab, 2013). The policy contains about maximizing the potential of renewable energy sources by using environmentally friendly fuels and the use of biofuels in various economic sectors in Malaysia (Chin, 2011). The next policy tends to be developing the potential of biofuels by providing supporting facilities and using biofuels as an alternative fuel mixture as listed on the Malaysia Act 666, the green technology policy.

The policy implication targets of carbon dioxide emission reduction in Philippines was referring to exploring biofuel potential resources. The policy applied is are developing and utilizing local clean energy resource to reduce dependence on imported energy, reducing the impact of greenhouse gases, improving the rural based socio-economic and ensuring the use of sustainable fuels. (Guzman, 2012; Corpuz and Verzani, 2014) The next policy is the target the use of biodiesel in all types of fuels, accelerating the development of renewable energy resources by providing intensive fiscal and nonfiscal for private investors and manufacturing producers / supplier to use biofuels and raw materials (Convento, Abacan and Acio, 2007; Guzman, 2012; Corpuz and Verzani, 2014).

Policy to reduce carbon dioxide emissions in Thailand focused on the exploration efforts of alternative renewable resources. Policies implemented including promoting technology commercialization related to potential energy sources, such as biofuels, biomass and biogas (Chirapanda, 2009). Focusing on the R \& D of new alternative energy technologies to develop alternative energy technology industry with an emphasis on the production of biofuels and introduce the development of the Green City model to the community for economic efficiency and Sustainable Development (Chirapanda, 2009: USDA, 2015). Then taking some advantages of the economic feasibility of the technology as an alternative energy to expand the model of Green City and drive to become a network of biofuels.

\section{CONCLUSION}

Climate change in ASEAN 4 is affected by economic conditions in each country. This study analyzes the dynamics of carbon dioxide emissions that proxy to analyze the risks of climate change in the ASEAN 4. The use of macroeconomic variables (GDP, Trade, Energy Consumption, and the exchange rate) is to investigate the determination of carbon dioxide emissions in the respective ASEAN 4 in order to measure the risk of climate change contributed by sectors of the economy. We use VARX analysis to 
provide an overview of each movement mutual influential of each macroeconomic variables on carbon dioxide emissions. The results of the empirical findings show that macroeconomic variables have contributed to the determination of carbon dioxide emissions in the ASEAN 4. It shows that state of the risk of global warming in each of the ASEAN 4 countries contributed by sectors of the economy. The right policies are expected to contribute to the risk of global warming. Through biofuels policies, ASEAN 4 countries seek to reduce the risks of climate change. The risk of global warming that has occurred in each of the ASEAN 4 countries are not fully contributed by sectors of the economy. Other forms of environmental degradation also have contributed to the change in seasons such as the burning of land, environmental pollution, and illegal logging. These conditions can provide conclusions related to the efforts to reduce the risk of global warming that can be done through reforestation and efficient use of energy consumption.

\section{REFERENCES}

Abrahamson, D. E. (2015).On economics and climatic change. Ecological Economics,114, 243-244. https://10.1016/j.ecolecon.2015.02.024.

Anderson, B. \& M'Gonigle, M. (2012) 'Does ecological economics have a future? Contradiction and reinvention in the age of climate change', Ecological Economics. , 84, . 37-48. https://10.1016/j.ecolecon.2012.06.009.

Ang, B. W. \& Goh, T. (2016). Carbon intensity of electricity in ASEAN: Drivers, performance and outlook, Energy Policy, 98 . 170-179. https://10.1016/j.enpol.2016.08.027.

Apergis, N. (2016). Environmental Kuznets curves: New evidence on both panel and country-level CO2 emissions, Energy Economics, 54, . 263-271. https://10.1016/j.eneco.2015.12.007.

Ariwa, F. O., Ani, O. I., Onyele, K. O., Ekeleme, I. J. \& D, O. O. P. (2017). Impact of Stock Market Liquidity and Efficiency on Performance of the Manufacturing Sector in Nigeria ( 1985-2014). International Journal of Economics and Financial Management, 2(1), . 71-82. Available at: www.iiardpub.org.

Arvin, M. B., Pradhan, R. P. \& Norman, N. R. (2015). Transportation intensity, urbanization, economic growth, and $\mathrm{CO} 2$ emissions in the G-20 countries. Utilities Policy. 35, . 50-66. https://10.1016/j.jup.2015.07.003.

Brown, K. E., Henze, D. K. \& Milford, J. B. (2017). How accounting for climate and health impacts of emissions could change the US energy system. Energy Policy. 396-405. https://10.1016/j.enpol.2016.12.052.

Chalise, S., Naranpanawa, A., Bandara, J. S. \& Sarker, T. (2017). A general equilibrium assessment of climate change-induced loss of agricultural productivity in Nepal. Economic Modelling, 43-50. https://10.1016/j.econmod.2017.01.014.

Chandran, V. G. R. \& Tang, C. F. (2013). The impacts of transport energy consumption, foreign direct investment and income on $\mathrm{CO} 2$ emissions in ASEAN-5 economies. Renewable and Sustainable Energy Reviews, 24,445-453. https://10.1016/j.rser.2013.03.054.

Chen, S., Chen, X. \& Xu, J. (2016). Impacts of climate change on agriculture: Evidence from China', Journal of Environmental Economics and Management,76, 105-124. https://10.1016/j.jeem.2015.01.005.

Chin, M. (2011). Biofuels in Malaysia: An analysis of the legal and Infrastructural frame work. Working Paper, 23-35. https://10.17528/cifor/003470.

Chirapanda, S. (2009).Status and Potential for the Development of Biofuel and Rural Renewable Energy: Thailand.

Colenbrander, S., Gouldson, A., Sudmant, A. H. \& Papargyropoulou, E. (2015). The economic case for low-carbon development in rapidly growing developing world cities: A case study of Palembang, Indonesia, Energy Policy, 80, 24-35. https://10.1016/j.enpol.2015.01.020.

Convento, D. G. M., Abacan, J. P. \& Acio, F. M. (2007). Biofuels : A Review of Philiine Studies. 1-97.

Corpuz, P. \& Verzani, W. (2014). Philiine Biofuels Situation and Outlook. Available at: 
http://gain.fas.usda.gov/Recent GAIN Publications/Biofuels Annual_Manila_Philiines_10-222014.pdf.

Daniels, P. L. (2010). Climate change, economics and Buddhism - Part 2: New views and practices for sustainable world economies. Ecological Economics , 69, 962-972. https://10.1016/j.ecolecon.2010.01.012.

Ding, H., Chiabai, A., Silvestri, S. \& Nunes, P. A. L. D. (2016). Valuing climate change impacts on European forest ecosystems. Ecosystem Services, 18, 141-153. https://10.1016/j.ecoser.2016.02.039.

Gowdy, J. M. (2008). Behavioral economics and climate change policy. Journal of Economic Behavior and Organization, 68, . 632-644. https://10.1016/j.jebo.2008.06.011.

Guzman, R. B. de (2012). The Renewable Energy Act of 2008 (R. A. No. 9513) Implementation 1. 2008(9513).

Halkos, G. E. \& Tsilika, K. D. (2017). Climate change effects and their interactions: An analysis aiming at policy implications. Economic Analysis and Policy, 53,140-146. http://dx.doi.org/10.1016/j.eap.2017.01.005.

Hanif, A. (2011). The Determinants of Non-Tariff Barriers in Malaysia's Manufacturing Sector, 2001. International Conference on Economics and Business Information, 9, . 9-16.

Jaung, W., Putzel, L., Bull, G. Q., Kozak, R. \& Markum (2016). Certification of forest watershed services: A Q methodology analysis of oortunities and challenges in Lombok, Indonesia. Ecosystem Services, 22, 51-59. https://10.1016/j.ecoser.2016.09.010.

Lopez, G. P. \& Laan, T. (2008). Biofuels - at what cost? Government suort for biodiesel in Malaysia, The International Institute for Sustainable Development. Avaliable at https://978-1-894784-22-1 i.

Medrilzam, M., Smith, C., Aziz, A. A., Herbohn, J. \& Dargusch, P. (2017). Smallholder Farmers and the Dynamics of Degradation of Peatland Ecosystems in Central Kalimantan, Indonesia', Ecological Economics. , 136, . 101-113. https://10.1016/j.ecolecon.2017.02.017.

Mugableh, M. I. (2013) 'Analysing the CO2 Emissions Function in Malaysia: Autoregressive Distributed Lag Aroach', Procedia Economics and Finance, 5, 571-580. https://10.1016/S22125671(13)00067-1.

Mujiyanto, S. \& Tiess, G. (2013). Secure energy suly in 2025: Indonesia's need for an energy policy strategy', Energy Policy, 61, 31-41. https://10.1016/j.enpol.2013.05.119.

Ng'ang'a, S. K., Bulte, E. H., Giller, K. E., McIntire, J. M. \& Rufino, M. C. (2016). Migration and SelfProtection Against Climate Change: A Case Study of Samburu County, Kenya. World Development, 84, 55-68. https://10.1016/j.worlddev.2016.04.002.

Othman, M. R., Martunus, Zakaria, R. \& Fernando, W. J. N. (2009). Strategic planning on carbon capture from coal fired plants in Malaysia and Indonesia: A review. Energy Policy, 37, 1718-1735. https://10.1016/j.enpol.2008.12.034.

Rosen, R. A. \& Guenther, E. (2016). The energy policy relevance of the 2014 IPCC Working Group III report on the macro-economics of mitigating climate change. Energy Policy, 93, 330-334. https://10.1016/j.enpol.2016.03.025.

Saboori, B., Sulaiman, J. \& Mohd, S. (2012). Economic growth and CO 2 emissions in Malaysia: A cointegration analysis of the Environmental Kuznets Curve. Energy Policy, 51, 184-191. https://10.1016/j.enpol.2012.08.065.

Skidmore, S., Santos, P. \& Leimona, B. (2014). Targeting REDD+: An Empirical Analysis of Carbon Sequestration in Indonesia, World Development, 64, 781-790. https://10.1016/j.worlddev.2014.07.013.

Spalding-fecher, R., Joyce, B. \& Winkler, H. (2017). Climate change and hydropower in the Southern African Power Pool and Zambezi River Basin: System-wide impacts and policy implications', Energy Policy, 103, 84-97. https://10.1016/j.enpol.2016.12.009.

Tsigaris, P. \& Wood, J. (2016). A simple climate-Solow model for introducing the economics of climate change to undergraduate students. International Review of Economics Education, 23, 65-81. https://10.1016/j.iree.2016.06.002. 
USDA (2015). Thailand biofuels annual. GAIN Report Number TH9047, TH9047, . 1-11. Available at: http://www.globalbioenergy.org/uploads/media/0903_GAIN_Report_-_thai.biofuel.food.pdf.

Vale, P. M. (2016). The changing climate of climate change economics. Ecological Economics, 121,1219. https://10.1016/j.ecolecon.2015.10.018.

Wahab, A. G. (2013) 'Malaysia Biofuels Annual', USDA Foreign Agricultural Service, GAIN Report , . 110. Available at:

http://scholar.google.com/scholar?hl=en\&btnG=Search\&q=intitle:Malaysia+Biofuels+Annual\# 3.

Wardhono, A., Putra, P. T. N., \& Nasir, M. A. (2016). Causal study of macroeconomic indicators on carbon dioxide emission in ASEAN 5. Economics and Policy of Energy and the Environment, 2016(2), 15-31. https://doi.org/10.3280/EFE2016-002002

Yao, C. Z., Lin, Q. W. \& Lin, J. N. (2016). A study of industrial electricity consumption based on partial Granger causality network. Physica A: Statistical Mechanics and its Alications, 461, 629-646. https://10.1016/j.physa.2016.06.072.

Yu, L., Li, J., Tang, L. \& Wang, S. (2015). Linear and nonlinear Granger causality investigation between carbon market and crude oil market: A multi-scale aroach. Energy Economics, 51, 300-311. https://10.1016/j.eneco.2015.07.005.

Yu, Y., Wang, D. D., Li, S. \& Shi, Q. (2016). Assessment of U.S. firm-level climate change performance and strategy. Energy Policy, 92, 432-443. https://10.1016/j.enpol.2016.02.004.

Zhang, P., Zhang, J. \& Chen, M. (2017). Economic impacts of climate change on agriculture: The importance of additional climatic variables other than temperature and precipitation. Journal of Environmental Economics and Management, 83, 8-31. https://10.1016/j.jeem.2016.12.001. 